\title{
PRINSIP HIDUP KAWRUH BEGJA DALAM PERSPEKTIF ANTON BAKKER
}

\author{
Oleh:
}

Marsono

Dosen PAH Fakultas Dharma Acarya

Email: marsono.65.19@gmail.com

\begin{abstract}
This article outline aims to understand the principle of life in this kind of Javanese society based on Anton Bakker's metaphysical theory. Describes the position of the Javanese as being there among other creators in a structure of reality. Javanese people in this context are assumed to have metaphysics, namely placing themselves as subjects as well as objects of metaphysics, and occupying a position as a being for themselves as well as being for others. The principle of kawruh thus is more dominant showing mental aspects in the form of the soul but, it is emphasized again that the soul and the body remain a unity of reality inseparable with their respective roles. The Javanese do not merely look at reality through their own perspective, but also look at the physical reality of the world outside themselves, then see the range of connectedness between themselves and the reality outside themselves.
\end{abstract}

Keywords: Metaphysics, Life Principles, Java, Kawruh Begja

\begin{abstract}
Abstrak
Artikel ini secara garis besar bertujuan untuk memahami prinsip hidup kawruh begja dalam masyarakat Jawa berdasarkan teori metafisika Anton Bakker. Memaparkan kedudukan orang Jawa sebagai pengada yang berada di antara pengada-pengada lain di dalam suatu struktur realitas. Manusia Jawa dalam konteks ini diandaikan bermetafisika, yakni menempatkan dirinya sebagai subjek sekaligus sebagai objek metafisika, serta menempati posisi sebagai pengada bagi dirinya sendiri sekaligus pengada bagi orang lain. Prinsip kawruh begja memang lebih dominan memperlihatkan aspek mental yang berupa jiwa tetapi, ditekankan kembali bahwa jiwa dan badan tetaplah merupakan kesatuan realitas yang tak terpisahkan dengan perannya masing-masing. Orang Jawa pun tidak semata-mata memandang realitas melalui perspektif dirinya, tetapi juga memandang realitas fisik dunia di luar dirinya, kemudian melihat jangkauan keterhubungan antara dirinya dengan realitas di luar dirinya.
\end{abstract}

Kata Kunci: Metafisika, Prinsip Hidup, Jawa, Kawruh Begja 


\section{PENGANTAR}

Hal pertama yang terlintas di dalam pikiran ketika membicarakan studi kefilsafatan tentang metafisika dan atau ontologi ialah sesuatu tentang yang ada beserta realitas ada. Sepanjang perkembangan kajian metafisika beriringan dengan perkembangan zaman, muncul berbagai konsep, teori, ataupun pandangan metafisis yang amat beragam. Berbagai pandangan dalam kajian metafisika dengan argumen yang diajukan oleh masing-masing paham, aliran, ataupun tokoh/ filsuf, menunjukkan bahwa terdapat beragam bentuk pemaknaan terhadap metafisika. Setiap pemikir memiliki pemahaman serta pemaknaan yang begitu beragam terhadap pandangan tentang realitas dan konsep ada.

Filsafat pada tataran non-akademis berbicara tentang persoalan-persoalan yang serupa dengan filsafat pada tataran akademis. Hal ini menyiratkan bahwa manusia senantiasa haus akan penjelasan-penjelasan yang mengatasi kenyataan yang dijalaninya sehari-hari. menjelaskan suatu fakta bahwa manusia yang mempertanyakan persoalan-persoalan yang luar biasa jauh dalam lingkupnya dan persepsinya menunjukkan rasa kehausan bagi tiap manusia untuk mendapatkan penjelasan, hal tersebut menunjukkan bahwa setiap orang telah berfilsafat walaupun dengan sebuah pertanyaan yang paling sederhana. Setiap orang memiliki filsafat walaupun orang mungkin tidak sadar akan hal tersebut (Titus 1984: 5-11).

Ada beberapa pendapat dalam metafisika, salah satu pendapat metafisik yang menyusun suatu sistem adalah pendapat yang menerima suatu prinsip pertama di belakang gejala-gejala, prinsip-prinsip inilah yang memberi makna dan hukum kenyataan. Prinsip azali, dalam hal ini dianggap sebagai kenyataan yang sesungguhnya, pada umumnya di ambil dari skema tradisional. Prinsip pertama atau azali ini ada yang-material, ada yang-hidup, ada yang-rohani dan ada yangilahi (Siswanto, 1998: 4).

Salah satu tokoh yang memiliki konsep metafisika tentang realitas pengada sebagai subjek dan realitas pengada sebagai objek adalah Anton Bakker. Konsep metafisika Bakker tentang cara pandang terhadap realitas secara lebih spesifik mengacu pada objek diskusi seputar manusia, seperti halnya jiwa dan raga sebagai sebuah kesatuan realitas yang representatif. Dimensi metafisika Bakker yang diturunkan ke dalam sejumlah bagian dapat menjadi 'pisau analisis' persoalan metafisika, khususnya berkaitan dengan aspek kehidupan serta pandangan hidup manusia terhadap realitas dunia.

Psikolog Jawa yang banyak memberikan dasar pemahaman hidup melalui aspek kejiwaan adalah Ki Ageng Suryamentaram, yang banyak memberikan wejangan psikologi Jawa berdasarkan pengalaman nyata tentang kehidupan tradisi Jawa. Pengalaman nyata baginya adalah guru terbaik. Pengalaman psikologis justru lebih penting dibandingkan pengalaman yang lain, karena manusia melalui olah jiwa dapat semakin tahu tentang siapa dirinya. Tahu tentang diri berarti tahu tentang hakikat hidup dan mati, sehingga kemudian tahu tentang hakikat jiwa dan raga (Endraswara, 2013: 212). 
Adapun objek material yang digunakan sebagai fokus kajian dalam artikel ini yaitu pandangan hidup orang Jawa kawruh begja, yakni sebuah konsep yang berisi prinsip hidup, kaarakter dasar, kepribadian, serta landasan kehidupan bagi orang Jawa. Secara sekilas kawruh begja menggambarkan unsur kejiwaan yang dominan dalam menggambarkan pandangan umum orang Jawa terhadap realitas dunia, tetapi penelusuran lebih lanjut menynjukkan bahwa orang Jawa juga menjadikan unsur raga sebagai jalan untuk memahami struktur realitas dunia. Objek formal yang digunakan untuk menganalisis objek material tersebut ialah konsep metafisika Anton Bakker yakni kesatuan dan kejamakan, otonomi dan korelasi, sifat pengada, kejasmanian dan kerohanian, serta norma pengada.

\section{PEMBAHASAN}

\section{A. Metafisika Anton Bakker Sebagai Kerangka Teoretis}

\section{Otonomi-Korelasi dan Kebanyakan- Kesatuan}

Persoalan mengenai kebanyakan dan kesatuan secara umum berhubungan dengan pertanyaan: apakah realitas itu tunggal atau jamak? Persoalan tersebut merupakan persoalan metafisika -yang secara khusus ontologipaling fundamental karena menentukan sudut pandang pertama mengenai kenyataan dan memberi arah utama bagi seluruh ontologi. Pertanyaan tersebut menyangkut dua macam aspek yaitu aspek ekstensif yang berhubungan dengan pertanyaan: apakah keseluruhan kenyataan tunggal ataukah majemuk? Serta, aspek komprehensif yang berhubungan dengan pertanyaan: apakah keseluruhan kenyataan seragam atau bermacam ragam (Bakker, 1992: 25).

Persoalan mengenai otonomi dan korelasi menduduki tempat pertama bukan karena satu hal yang kebetulan ataupun asal-asalan. Anton Bakker menempatkan persoalan otonomi dan korelasi, atau persoalan kebanyakan dan kesatuan pada posisi pertama karena persoalan tersebut berkaitan dengan aspek kuantitas realitas. Artinya, persoalan mengenai hal yang banyak dan hal yang satu menjadi pertanyaan paling mendasar dalam kajian metafisika, yakni mengerucut pada pertanyaan tentang apakah kenyataan atau realitas adalah tunggal atau jamak?

Sepanjang perjalanan sejarah filsafat, khususnya metafisika, sudah banyak filsuf yang berusaha menjawab pertanyaan paling fundamental dalam metafisika. Jawaban yang berorientasi monistis dan pluralistis adalah dua aliran yang menjadi kecenderungan para filsuf di dalam menjawab persoalan tersebut. Anton Bakker menjawab pertanyaan demikian dengan menyatakan bahwa metafisika harus bertolak dari kenyataan konkret. Titik pangkal kajian ataupun penelitian metafisika ialah kesadaran manusia mengenai dirinya sendiri sebagai data. Hal tersebut pun sesuai dengan kedudukan fundamental dari pertanyaan kesatuan dan kejamakan tersebut, jawaban atas persoalan tersebut akan membantu memperjelas kemungkinan ontologi, objek, serta metode yang digunakan (Bakker, 1992: 26). 


\section{Sifat-Sifat Pengada}

Tugas metafisika dan khususnya ontologi adalah mencari sifat otonomi dan korelasi sebagai sifat hakiki yang ada. Metafisika bertugas untuk memberikan keterangan apakah otonomi dan korelasi sama ataukah berbeda. Sepanjang sejarah perjalanan metafisika, kecenderungan para filsuf dapat dirangkum ke dalam dua sikap. Pertama, jawaban yang menganggap adanya kesamaan sifat dalam pengada-pengada yang berbeda. Kedua, jawaban yang menganggap adanya banyak sifat berbeda-beda dalam pengadapengada (Bakker, 1992: 57-61).

Persoalan mengenai sifat-sifat pengada ini menurut Bakker diaplikasikan metafisika ketika menganalisis pengada sebagai data untuk dirumuskan ontologi. Persoalan kedua pun dapat dipahami melalui dua hal sekaligus. Pertama, pengada dalam kedudukannya sebagai data seperti manusia, hewan, atau tumbuhan. Kedua, pengada dalam kedudukannya sebagai realitas terdalam yakni dalam kaitannya dengan persoalan pertama, contohnya pandangan manusia akan suatu realitas terdalam sebagaimana manusia memaknai pemahaman suatu realitas terdalam atau manusia sebagai sebuah representasi dari realitas terdalam itu sendiri. Hal tersebut menunjukkan bahwa ketika metafisika berhasil mendapatkan jawaban mengenai apakah kenyataan itu tunggal ataukah jamak, maka dalam rangka mendapatkan gambaran umum mengenai struktur realitas, metafisika harus mencari tahu sifat-sifat realitas yang menjadi hakikat terdalam tersebut (Siswanto \& Wikandaru, 2013: 130).

\section{Dinamika Pengada}

Persoalan tentang dinamika yang ada berkaitan dengan pertanyaan: apakah pengada pertama-tama permanen dan tetap, ataukah hanya sementara atau kontingen saja? Pertanyaan tersebut pun kemudian menyangkut dua aspek. Pertama, berhubungan dengan pertanyaan: apakah yang ada selalu mengalami proses dan tidak pernah bersifat statis/ tetap? Kedua, berhubungan dengan pertanyaan: apakah yang ada mengalami kelahiran dan kematian? (Bakker, 1992: 77).

Persoalan dinamika pengada menurut Bakker muncul dari pengamatan terhadap fakta yang ada yakni bahwa setiap pengada memiliki dinamika tersendiri dalam menjalani "keberadaannya". Manusia, hewan, dan tumbuhan secara empiris memperlihatkan dinamika dalam setiap fase kehidupan seperti lahir, tumbuh, menua, hingga kemudian mati. Berbedahalnya dengan pengadayanglain seperti pengada anorganik, batu dan tanah. Dinamika yang dialamo oleh pengada anorganik tidak begitu mudah diketahui, karena seolah-olah tetap serta tidak mengalami kematian seperti halnya dialami oleh pengada organik. Fakta empiris akan kelahiran dan kematian pengada pun menyangkut persoalan mengacu pada dua hal yakni pengada itu permanen ataukah tetap, serta sementara ataukah kontingen. Dua hal tersebut pun kemudian menyangkut dua aspek yang ditunjukkan melalui pertanyaan dari masing-masing aspek. Pertama, apakah yang ada selalu mengalami proses dan tidak pernah bersifat statis atau tetap? Kedua, apakah yang ada mengalami kelahiran dan 
kematian? Lalu, apabila pengada pengalami kelahiran dan kematian, bagaimanakah jalannya? Bakker kemudian berpendapat bahwa pertanyaan tersebut dapat diketahui jika terlebih dahulu mencari tahu kaitannya dengan persoalan ketiga yakni persoalan hakikat struktural dari pengada-pengada dengan segala konsekuensinya (Bakker, 1992: 77-78).

\section{Kejasmanian dan Kerohanian}

Metafisika sebagai ilmu yang berusaha menjelaskan gambaran umum realitas, juga berusaha memberikan jawaban atas pertanyaan: apakah seluruh kenyataan bersifat jasmani ataukah rohani? Pertanyaan demikian menunjukkan maksud lain yang mengacu pada pertanyaan lanjut, adakah kemungkinan kenyataan merupakan gabungan dari jasmani dan rohani? (Bakker, 1992: 103). Untuk menguraikan kemungkinan maksud tersebut, secara ilmiah dapat dijelaskan melalui analisis hakikat manusia. Hal demikian disebabkan oleh pendapat Anton Bakker yang menyatakan bahwa manusia dan alam ataupun kosmos, merupakan bahan refleksi awal untuk memahami kenyataan.

Refleksi awal untuk bermetafisika pun dapat terfokus pada dua persoalan. Pertama, persoalan kejamakan dan kesatuan memiliki keterkaitan dengan aspek kuantitas realitas. Kedua, persoalan kejasmanaian dan kerohanian memiliki hubungan dengan aspek kualitas realitas. Persoalan yang ditunjukkan melalui dua pertanyaan tersebut merupakan penentu arah di dalam kajian ataupun diskusi ontologi (Siswanto \& Wikandaru, 2013: 132).
Persoalan mengenai kejasmanian dan kerohanian telah melahirkan perdebatan panjang. Ada setidaknya tiga pendapat yang dapat dirangkum sebagai gambaran atas jawaban yang dikemukakan oleh para filsuf. Pertama, spiritualisme yang menganggap bahwa realitas pada hakikatnya adalah roh. Kedua, materialisme yang menganggap bahwa kenyataan pada hakikatnya adalah materi atau bersifat jasmani. Ketiga, dualisme yang menganggap bahwa hakikat realitas adalah bagian dari substansi jasmai dan rohani (Bakker, 1992: 103).

\section{Norma Pengada}

Setelah diketahui unsur-unsur transendental dan struktural dari pengada secara keseluruhan, kemudian timbul pertanyaan: apakah kiranya struktur hakiki pengada memuat aspek normatif? Jika pertanyaan tersebut dapat dijawab, maka akan dapat diberikan perspektif total-ontologis mengenai segala aspek normatif yang ada pada setiap taraf pengada (Bakker, 1992: 194).

Persoalan norma pengada memang terletak pada bagian akhir dari masalah metafisika karena persoalan ini baru muncul setelah diketahui unsur-unsur transendental dan struktural pengada secara keseluruhan. Ada beberapa rumusan pertanyaan yang dapat dikemukakan kaitannya dengan persoalan tersebut. Pertama, apakah kiranya struktur hakiki pengada memuat aspek normatif? Kedua, apakah di samping memiliki kepadatan struktural tertentu, para pengada dengan ukuran lebih atau kurang memenuhi suatu kaidah atai tolo ukur ontologis? Ketiga, apakah mengada itu selalu entah benar dan baik, atau palsu dan 
jelek. Keempat, norma ontologis-transendental yang demikian dapat berarti apa? Bakker kemudian menyatakan, apabila persoalanpersoalan tersebut mendapatkan jawaban, maka perspektif total-ontologis mengenai segala aspek normatif yang ada pada setiap taraf pengada akan terlihat (Bakker, 1992: 194).

\section{B. Kearifan Lokal Jawa Dalam Filosofi Hidup}

\section{Kawruh begja}

\section{Kawruh begja Sebagai Pandangan Hidup}

\section{Orang Jawa}

Kearifan lokal atau yang juga populer dikenal dengan istilah local genius, merupakan sebuah pilar pemikiran orang Jawa yang hebat, yang merujuk pada sebuah pemikiran berdasarkan watak tradisi. Orang Jawa yang tidak sekedar mengembangkan pemikiran tentang kehidupan, kearifan lokal tersebut pun telah berbaur dengan rasa. Pikiran dan rasa Jawa itulah yang bercampur manis, sehingga membuat orang Jawa lebih bijaksana (Endraswara, 2003: 211).

Local genius yang sampai sekarang masih bertahan dalam kehidupan orang Jawa gagasan psikologi Jawa yakni karwuh kejiwaan Jawa atau kawruh begjan. Kearifan lokal kawruh begjan merupakan satu filosofi ataupun pandangan hidup orang Jawa yang meliputi gejolak nalar, rasa, serta keinginan orang Jawa dalam melangsungkan hidup. Orang Jawa pada umumnya hidup di dalam dunia kejiwaan yang dalam. Penguasaan jiwa yang matang dan terlatih inilah yang membedakan psikologi Jawa dengan psikologi lain (Endraswara, 2003: 211).
Jiwa dalam pandangan orang Jawa selalu mobah mosik atau bergerak. Riak gelombang jiwa sering disebut makarti. Aktivitas jiwa akan seirama dengan gelombang air laut, tak pernah terhenti, dan mungkin bisa lebih dahsyat daripada air laut sebagaimana ombak besar yang menerjang daratan. Jiwa tak kelihatan atau tak kasat mata dan hanya dapat dimengerti melalui gejala raga atau fisik manusia. Jiwa dan raga sama-sama penting di dalam kehidupan manusia, orang Jawa mengatakan, ibarat isi dan wadah. Jiwa dan raga saling melingkupi dan saling mengisi satu sama lain, serta saling mendukung kehidupan manusia (Endraswara, 2013: 212).

Menurut wawasan psikolog Jawa, RM. Sosrokartono, hidup tak harus memiliki japa mantra yang muluk-muluk dan dalil yang pelikpelik. Hidup cukup berpegang pada perbuatan yang disebut caturmurti, yakni perpaduan empat hal dalam jiwa manusia seperti pikiran, perasaan, perkataan, dan perbuatan. Perpaduan empat hal tersebut dalam pandangan Jawa disebut kasunyatan atau kenyataan. Barang siapa menjalankan perbuatan sesuai kenyataan, akan mendapatkan kasunyatan. Wawasan psikologi semacam ini menggambarkan bahwa perbuatan merupakan cermin jiwa manusia. Manakala perbuatan sejalan dengan jiwa, dianggaplah sebagai orang yang lurus dan baik. Oleh sebab itu, sesungguhnya manusia memiliki sifat baik. Manusia baru memiliki sifat jelek ketika terpengaruh berbagai faktor kehidupan (Ciptoprawiro, 1996: 13).

$\mathrm{Ki}$ Ageng Suryamentaram juga mengenalkan konsep hidup pembangun jiwa 
tentang bungah sajroning susah, artinya ketika manusia sedang dilanda kesedihan hendaknya diterima dengan senang hati. Penerimaan demikian hanya mampudilakukan oleh orang yang endapan rasanya telah kental. Bungah dan susah hanyalah sementara. Keduanya akan mengalami perputaran atau cakramanggilingan, sehingga manusia diharapkan menerima dua keadaan itu secara sadar (Endraswara, 2013: 2013).

\section{Watak Nrima dan Rasa Rumangsa Orang} Jawa

$\mathrm{Ki}$ Ageng Suryamentaram memberi wejangan tentang kawruh begja sawetah yaitu hidup yang didasarkan pada konsep sabutuhe, saperlune, sacukupe, sakpenake, samesthine, lan sabenere. Maksudnya, hidup tak harus nggaya dan atau ngrangsang. Hidup sebaiknya apa adanya. Realita hidup justru lebih menyenangkan dibandingkan banyak fantasi atau keinginan terlalu jauh dari kenyataan seperti fatamorgana. Hidup yang demikian ialah hakikat hidup orang Jawa, tidak perlu mengada-adakan yang tak mungkin. Hidup yang hakiki adalah penting dan lebih menenangkan jiwa, karena hidup yang terlalu banyak tuntutan hanya akan menjadi beban psikologis, membuat semasa hidup tak pernah tenteram (Endraswara, 2013: 213-214).

Watak dasar orang Jawa semacam itu yang menjadi fondasi sikap nrima, yakni menerima segala sesuatu dengan kesadaran spiritual-psikologis, tanpa merasa nggrundel atau menggerutu karena kecewa. Apapun yang diterima dianggap sebagai karunia Tuhan. Pada saat itu, hanya watak lamun kelangan ora gegetun, trima mawi pasrah, artinya dalam hal apapun haruslah diterima dengan kesungguhan hati, dan yang terpenting adalah hidup dengan usaha sampai semaksimal mungkin, baru setelah itu nrima. Usaha merupakan jembatan nasib. Oleh sebab itu, apabila usaha gagal maka orang Jawa akan menerima sebagai sebuah pelajaran (Endraswara, 2013: 214).

Nrima bukan berarti menyerah begitu saja tanpa melakukan usaha keras. Nrima hanyalah sandaran psikologis, yang di balik itu berpedoman ana dina ana upa, obah mamah. Artinya, jika masih ada hari, rejeki tentu ada, dan setiap orang yang mau bekerja tentu akan meraih rejeki. Bahkan orang Jawa selalu berprdoman, golek pangan sewu dalane, artinya banyak jalan untuk mencari rejeki halal. Pendek kata, melalu nrima dan usaha kupiya maka keberuntungan kabegjan akan datang. Apabila nrima tersebut disertai pasrah sumarah, maka sangat mungkin kabegjak datang dengan sendirinya (Endraswara, 2013: 214).

Rasa rumangsa adalah inti wawasan psikologi Jawa. Melalui rasa rumangsa, orang Jawa akan mengukur diri. Cermin diri orang Jawa, baik cermin buram maupun bening tetap penting. Rasa rumangsa merupakan endapan rasa, yang mencoba melihat diri, yang diawali dengan sikap mengaca diri dan beranimerasakan jerih payah yang dialami orang lain. Rasa pangrasa merupakan benteng tindakan orang Jawa agar tak berbuat melanggar aturan atau norma. Orang Jawa senantiasa merasa bahwa 
dirinya ada yang mengawasi, merasa dicintai dan diperhatikan oleh orang lain. Dengan cara ini, sikap humanis semakin terpupuk.

Melalui rasa rumangsa akan mudah mawas diri. Orang Jawa yang pandai mawas diri akan bersikap demokratis dan humanis. Orang tersebut akan bijak dan tidak mengadaada. Pada akhirnya mereka akan bisa rumangsa yakni bisa merasakan dan tidak sekadar rumangsa bisa yaitu merasa mampu. Sikap bisa rumangsa akab menyadarkan diri bahwa dirinya sejajar dengan orang lain, karena apa yang dirasakan berat oleh dirinya jika menimpa orang lain pun akan terasa sama beratnya (Endraswara, 2013: 215).

\section{Hati Nurani dan Rahsa Sebagai Kepribadian Orang Jawa}

Pribadi orang Jawa memang unik. Umumnya orang Jawa lebih tertutup dalam segala hal. Manifestasi dari kepribadian tertutup ini, terlihat dari segala hal yang selalu disampaikan secara tertutup, halus, dan bermakna. Perilaku bahasa cukup lemah lembut, terlebih lagi di Jawa mengenal ragam krama alus dan ngoko/ kasar. Dalam rasa Jawa juga nampak pada aktivitas publik yang selalu rendah diri dalam bergaul dengan sesama. Orang Jawa pun pandai berbasa-basi demi membahagiaan orang lain. Orang Jawa tidak mau terbuka setiap saat, orang Jawa hanya akan tinarbuka/ terbuka hanya pada waktu dan pada tempat tertentu, kepada orang yang tertentu juga (Endraswara, 2013: 218).

Kehalusan rasa amat tampak ketika orang Jawa telah menginjak usia remaja sampai dewasa dengan kematangan emosi yang semakin stabil dan terjaga. Rasa dalam budaya Jawa tak sekadar emosi, tetapi perpaduan intuisi, akal, dan nalar sehat. Rasa pada dasarnya terbagi menjadi dua golongan yaitu rasa njaba/ kasar dan rasa njero/ halus yang saling mengisi. Rasa njaba sebagian didorong oleh nafsu dan insting, sedangkan rasa njero merupakan gejolak kesadaran jiwa yang dalam. Kedalaman jiwa dalam kehidupan orang Jawa terletak pada hati nurani, karena rasa sadar merupakan bentuk dari hati nurani. Ibarat bilik kesadaran jiwa yang terdalam, hati nurani berfungsi mengarahkan sebuah keputusan yang diambil oleh orang Jawa. Rasa didorong oleh rahsa yaitu suatu endapan pengalaman batin. Rahsa berarti kehalusan rasa yakni lubuk hati nurani mendalam (Endraswara, 2013: 221).

Kepribadian dan kesucian hati Jawa selalu menyatukan tiga hal yaitu ati temen sebagai tapa ati, tapa nyawa terletak pada watak eling/ ingat, dan tapa rasa pada watak hening. Perpaduan antara watak temen, eling, dan hening akan membuahkan rasa sejati yang membimbing rasa lain. Rasa sejati adalah penyeimbang inti rasa yang terbelah menjadi dua yaitu susah dan bungah, yang selalu bertarung dalam jiwa (Endraswara, 2013: 221).

C. Analisis Tinjauan Metafisika Anton Bakker Dalam Prinsip Hidup Orang Jawa Kawruh begja

1. Kawruh begja: Ati Menep Wujud Endapan Batin dari Proses Kejasmanian dan Kerohanian Orang Jawa

Konsep kawruh begja sebagimana telah diungkapkan oleh tokoh $\mathrm{Ki}$ Ageng 
Suryamentaram memberikan pemahaman akan pandangan orang Jawa terhadap realitas dunia di dalam dan di luar dirinya sebagai upaya mencapai tujuan kebahagiaan jiwa melalui prinsip hidup khas orang Jawa. Adapun cara pencapaian prinsip hidup kawruh begja apabila dianalisis melalui perspektif struktur jasmani dan rohani Anton Bakker, merujuk pada kemungkinan ketiga yang menganggap perpaduan antara roh dan badan demi mencapai pemahaman akan struktur realitas. Konteks realitas dalam hal ini ialah pencapaian kebahagiaan jiwa.

Sekilas, prinsip kawruh begja memang lebih dominan memperlihatkan aspek mental yang berupa jiwa. Akan tetapi, ditekankan kembali bahwa jiwa dan badan tetaplah merupakan kesatuan realitas yang tak terpisahkan dengan perannya masing-masing. Adanya proses dari aktivitas jiwa dan badan atau yang disebut Bakker sebagai jasmani dan rohani, pada satu titik akan bermuara pada rasa sebagai endapan pengalaman manusia. Oleh sebab itu, aspek kejasmanian dan kerohanian merupakan dua hal vital dalam memulai kajian kawruh begja yang ditinjau dari metafisika Anton Bakker. Aspek kejasmanian dan kerohanian merupakan titik tolak pengada dalam bermetafisika guna memahami struktur realitas kompleks baik di dalam diri maupun di luar dirinya.

Ati menep sebagai satu istilah Jawa yang menunjukkan pengertian bahwa manusia dengan ati menep memiliki rasa yang tenang, tenteram, bahagia, dan memiliki pemikiran jernih dalam memahami realitas dunia. Ati menep sebagai satu bentuk dari jernihnya jiwa dan pikiran menunjukkan tercapainya prinsip kawruh begja orang Jawa. Dengan begitu, orang Jawa sebagai pengada yang dalam bagian struktur realitas ini dapat mengambil sikap metafisis bagi dirinya ataupun bagi lingkungan dan pengada lain di luar dirinya secara relasional.

\section{Otonomi-korelasi dan Kejamakan-} kesatuan sebagai Wujud Realitas Relasional dalam Kehidupan Orang Jawa

Pandangan tentang struktur realitas seperti halnya dimaknai oleh orang Jawa, termanifestasikan dalam berbagai bentuk dan sifat. Orang Jawa yang dikenal banyak membaurkan berbagai rasa di dalam jiwanya, tetap melihat adanya peran dari jiwa dan raga. Orang Jawa pun tidak semata-mata memandang realitas melalui perspektif dirinya, tetapi juga memandang realitas fisik dunia di luar dirinya, kemudian melihat jangkauan keterhubungan antara dirinya dengan realitas di luar dirinya. Oleh sebab itu, bentuk pembauran rasa yang menjadi muara dari proses orang Jawa sebagai pengada yang telah bermetafisika, tidak menunjukkan suatu finalitas di dalam proses bermetafisika, karena pembauran rasa dalam jiwa orang Jawa dapat bergejolak seiring dengan dinamika yang memberikan pengaruh terhadapnya.

Pembauran rasa yang ada sebagai aktivitas mental orang Jawa apabila ditinjau dari perspektif otonomi-korelasi dan kesatuankejamakan, menunjukkan bahwa orang Jawa memahami realitas dunia di luar dirinya dalam 
dasar otonomi yang terpisah-pisah, kemudian ketika orang Jawa menerima realitas dunia yang terpisah-pisah tersebut menggunakan aktivitas mental yaitu rasa, maka akan terlihat korelasi dari realitas dunia di luar dirinya yang terpisah-pisah tadi. Hal tersebut memberikan pengertian bahwa realitas dunia di luar diri manusia berorientasi otonom, artinya masingmasing pengada yang ada di luar diri manusia berada dengan batas dan karakteristik terpisah serta tidak dapat saling menjangkau. Situasi akan lain ketika menuju pada tataran korelasi yakni merujuk pada aktivitas mental orang Jawa, olah rasa, yang menghasilkan pembauran rasa di dalam diri orang Jawa yang kemudian dapat dijadikan sebagai bagian dari prinsip hidup kawruh begja -kembali mengingat arti kata begja yaitu jiwa-.

Adapun tinjauan olah rasa orang Jawa melalui perspektif kesatuan dan kejamakan, juga dipahami sebagaimana variabel otonomikorelasi, bahwa kesatuan yang ada berada pada tataran realitas di dalam diri manusia, sementara segala sesuatu yang jamak berada pada realitas dunia di di luar diri manusia seperti halnya dapat berupa pengada yang jamak. Hal tersebut diperkuat oleh patokan orang Jawa yang mengukur segala sesuatu dalam kehidupan melalui prinsip "aku kramadangsa", sehingga meskipun pembauran rasa diperoleh dengan memahami perasaan orang lain, namun prinsip "aku" dapat menjadi wujud muara prinsip hidup orang Jawa, bahwa realitas adalah "aku", tergantung "aku", sejauh pengambilan sikap yang akan "aku" ambil.

$$
\text { Dalam istilah } \mathrm{Ki} \text { Ageng }
$$

Suryamentaram, struktur kejiwaan manusia
Jawa ada dua yaitu keakuan kramadangsa dan rasa aku sejati. Di dalam kramadangsa terdapat catatan dan rasa hidup. Rasa merupakan gejolak jiwa ke arah individualitas atau pribadi, sifatnya sangat personal dan subjektif. Apabila hal-hal di luar diri manusia ternyata banyak mendukung hidup maka akan semakin tebal catatannya. Sebaliknya, jika catatan itu merugikan "aku", maka gairah kehidupan orang Jawa akan berkurang seiring dengan berkurangnya rasa, sehingga mengakibatkan orang Jawa putus asa dan tidak memiliki semangat hidup (Endraswara, 2013: 216-217).

\section{Filosofi Nrima dan Rasa Rumangsa sebagai Bentuk Penyatuan Orang Jawa \\ dengan Kenyataan dan Lingkungan}

Orang Jawa yang dikenal sering menerapkan sikap hidup nrima dalam kehidupan sehari-hari menunjukkan bahwa orang Jawa mengakui kenyataan mutlak akan dinamika kehidupan yang berada di luar kendali manusia. Sikap nrima dalam konteks ini pun tidak serta-merta diartikan sebagai sikap yang pasrah. Nrima dalam pengertian ini yakni setelah orang Jawa melakukan usaha maksimal untuk mencapai suatu keinginan. Dengan menerapkan sikap hidup nrima, orang Jawa dapat merenungkan berbagai kejadian yang dialami di tengah pengada lain di sekitarnya. nrima sebagai bentuk penyatuan diri orang Jawa dengan kenyataan dan lingkungan menunjukkan adanya kesatuan alur yang diikuti oleh orang Jawa demi mencapai ati menep.

Kunci mawas diri adalah pengawasan sikap. Petama adalah nandhing salira, artinya membandingkan kekurangan dan kelebihan 
dirinya dengan orang lain agar tak selalu merasa unggul/ dumeh, dan diharapkan lebih mampu memurba diri. Kedua adalah ngukur salira, artinya mampu mengukur orang lain dengan dirinya atau mengukur dirinya dengan perspektif orang lain. Dengan cara ini orang Jawa mampu merasakan apa yang dirasakan orang lain, sehingga dapat semakin waspada dalam mengambil sikap karena orang lain akan melakukan hal yang sama terhadap kita. Ketiga ialah tepa salira, artinya mampu merasakan apa saja yang dirasakan orang lain. Ukuran senang dan susah orang lain diukur diukur dari dirinya, karena orang Jawa menyatakan jika dicubit sakit jangan mencubit. Keempat ialah mawas diri, yaitu kemampuan memahami diri sejujurjujurnya. Dalam kaitan ini nurani akan banyak bermain. Nurani sulit dibohongi, maka orang yang jernih nuraninya akan mampu mawas diri dengan sebaik-baiknya. Kelima adalah mulat salira, orang Jawa mampu menemukan identitas atau karakteristik dirinya yang membedakan dengan orang lain (Endraswara, 2013: 215).

Wejangan kawruh jiwa tekniknya meliputi nyawang karep sebagai dimensi mawas diri yang diwujudkan dalam rasa manusia tanpa ciri yang merupakan pola berpikir rasional reflektif menuju kesadaran yang universal dan altruistik (Prihartanti, 2004: 76). Adapun bentuk lain penyatuan diri manusia Jawa dengan realitas nyata di luar dirinya terlihat dari tumbuhnya sikap bisa rumangsa yang diwujudkan melalui sebuah upaya mawas diri. Penyatuan diri manusia dengan lingkungan beserta pengada lain di luar dirinya yang digambarkan melalui mawas diri menunjukkan bahwa orang Jawa berupaya menjalin hubungan harmonis dengan lingkungan dan pengada lain di luar dirinya. Selain itu, penjelasan dari mawas diri tersebut menunjukkan bahwa orang Jawa selalu menimbang sebab dan akibat yang diterima dari sekitarnya, sehingga menunjukkan bahwa orang Jawa sebagai pengada juga menimbang segala hal dari pengada-pengada lain sebelum bertindak, menimbang pengaruh dirinya terhadap pengada lain di luar dirinya, serta menimbang hubungan timbal balik antara dirinya sebagai pengada yang berinteraksi dengan pengada lain di luar dirinya.

Hal tersebut apabila dibawa ke dalam kerangka teori metafisika Bakker, berkaitan dengan hubungan kegiatan dan penyebaban. Masalah berhubungan dengan pengada satu dan pengada yang lain yakni hubungan dalam tiga arti sekaligus. Pertama, aoakah pengada yang satu aktif mempengaruhi yang lain. Kedua, apakah pengada yang satu hanya pasif dipengaruhi oleh pengada yang lain. Ketiga, apakah pengada yang satu dengan yang lain saling memengaruhi. Persoalan kehiatan dan penyebaban berkaitan dengan hubungan pengada satu dan pengada yang lain (Bakker, 1992: 129).

Bila manusia mencoba memperluas pemahaman baru mengenai kehidupan ke ranah sosial maka akan menghadapi banyak fenomena yang membingungkan seperti aturan perilaku, nilai, maksud, cita-cita, strategi, desain, dan relasi kekuasaan. Menghadapi kebingungan tersebut manusia dapat mengambil sikap dengan mengambil pemahaman terhadap kesadaran reflektif yang berkaitan erat dengan konteks 
sosial. Lebih khusus lagi, kemampuan manusia untuk menyimpan citra-citra mental dari berbagai objek material dan peristiwa merupakan ciri pokok bagi munculnya ciri khusus kehidupan sosial. Kemampuan untuk menyimpan citra mental memperkenankan manusia untuk memilih diantara berbagai alternatif yang diperlukan untuk merumuskan berbagai nilai dan aturan perilaku sosial. Keinginan dan kesadaran manusia pada suatu tujuan merupakan desain serta strategi untuk mencapai cita-cita terentu memerlukan proyeksi citra mental ke masa depan (Setiawan, 2010: 45).

\section{Kesimpulan}

Tulisan tentang tinjauan metafisika Anton Bakker dalam prinsip hidup orang Jawa Kawruh begja ini secara garis besarmemaparkan kedudukan orang Jawa sebagai pengada yang berada di antara pengada-pengada lain di dalam suatu struktur realitas. Manusia Jawa dalam konteks ini diandaikan bermetafisika, yakni menempatkan dirinya sebagai subjek sekaligus sebagai objek metafisika, serta menempati posisi sebagai pengada bagi dirinya sendiri sekaligus pengada bagi orang lain. Adapun prinsip hidup orang Jawa Kawruh begja sebagaimana banyak diulas oleh tokoh terkenal Ki Ageng Suryamentaram, memang pada dasarnya merupakan sebuah konsep yang berorientasi kepada kajian psikologi. Akan tetapi, ada sejumlah aspek yang dapat dikaji melalui perspektif kajian kefilsafatan.

Adapun studi yang dapat digunakan untuk mengkaji konsep kawruh begja dalam paradigma kefilsafatan ialah studi metafisika. Pembahasan artikel ini menggunakan pandangan metafisika Anton Bakker mengingat latar belakang pemikiran
Bakker tentang metafisika yang juga banyak dipengaruhi atau bertolak dari kajian antropologi metafisik, sehingga terlihat bahwa ada relevansi antara pandangan metafisika Bakker yang berfokus pada objek kajian manusia dengan konsep kawruh begja Ki Ageng Suryamentaram yang berfokus pada jiwa dan atau psikologi manusia.

Kerangka teoretis metafisika Anton Bakker dalam artikel ini menggunakan aspek otonomikorelasi dan kesatuan-kejamakan, kejasmanian dan kerohanian, dinamika pengada, serta kegiatan dan penyebaban. Sementara prinsip hidup kawruh begja yang menjadi fokus kajian dalam artikel ini yaitu merujuk pada rasa orang Jawa sebagai kepribadian orang Jawa. Konsep rasa orang Jawa ini kemudian dikembangkan pada rasa rumangsa yang membawa posisi orang Jawa sebagai pengada di antara pengada-pengada yang lain lebih mawas diri. Oleh sebab itu, pemahaman akan konsep struktur realitas di sini cenderung pada implikasi sosial yang memandang orang Jawa sebagai bagian dari struktur realitas dengan menjalani kehidupan relasional bersama pengada-pengada lain.

\section{E. Daftar Pustaka}

Bagus, Lorens, 2000, Kamus Filsafat, PT Gramedia, Jakarta

Bakker, Anton. 1992. Ontologi atau Metafisika Umum Filsafat Pengada dan Dasar-dasar Kenyataan. Yogyakarta: Kanisius

Endraswara, Suwardi. 2013. Falsafah Hidup Jawa: Menggali Mutiara Kebijakan dari 
Intisari Filsafat Kejawen. Yogyakarta:

Cakrawala

Prihartanti, N. 2004. Kepribadian Sehat Menurut

Konsep Suryomentaram. Surakarta:

Muham-madiyah University Press

Setiawan, Otto Trengginas, 2010, Filsafat Holisme

Ekologis: Tanggapan terhadap

Paradigma Cartesian-Newtonian Menurut

Pemikiran Fritjof Capra, Fakultas

Ilmu Pengetahuan Budaya Program Studi

Filsafat Universitas Indonesia, Depok

Siswanto, Joko. 1998. Sistem-sistem Metafisika

Barat: dari Aristoteles sampai

Derrida. $\quad$ Yogyakarta: Pustaka

Pelajar

Siswanto, Joko dan Reno Wikandaru. 2013. Metafisika Nusantara: Belajar Kehidupan dari Kearifan Lokal. Yogyakarta: Gadjah Mada University Press 